\title{
Diversity and Abundance of Butterfly Species in the Abiriw and Odumante Sacred Groves in the Eastern Region of Ghana
}

\author{
Be atrice T. Nganso ${ }^{1, *}$, Rosina Kye re maten ${ }^{2}$, Daniel Obeng-Ofori ${ }^{3}$ \\ ${ }^{1}$ African Regional Postgraduate Programme in Insect Science (ARPPIS), University of Ghana, Legon, Accra, P. O. Box LG PMBL59, \\ Ghana \\ ${ }^{2}$ Department of Animal Biology and Conservation Science, Univ ersity of Ghana, Legon, Accra, P. O. Box LG 67, Ghana \\ ${ }^{3}$ College of Agriculture and Consumer Science, University of Ghana, Legon, Accra, P. O. Box LG PMB L 68, Ghana
}

\begin{abstract}
Sacred groves in Ghana have been adopted as one of the strategies to mitigate the loss of biodiversity. They are seriously under threat from anthropogenic activities. A six month survey of the butterfly fauna in the Abiriw and Odu mante sacred groves in the Akwapim North and South Districts, respectively of the Eastern Region of Ghana was conducted to characterize resident butterfly species diversity and abundance. The transect count method and charaxes traps were used to sample the butterflies. Analysis of butterfly diversity in these groves, which range in size from $400 \mathrm{~m}^{2}$ to $250 \mathrm{~m}^{2}$, was used to evaluate their effectiveness in achieving conservation objectives. Commun ity diversity was characterized in terms of, (a) number of species accumulated versus sampling effort, (b) nonparametric richness estimates, (c) Simpson's and Shannon-Weiner Indices of Diversity, and (d) Complementarity of communities. A total of 1169 ind ividual butterflies were trapped across all sites representing 89 species from 10 families. Butterfly species richness and evenness in the Abiriw grove was higher than that of the Odumante grove, however, the Abiriw grove harboured a resident community that was not distinctive from the Odumante grove. These findings add to the body of knowledge that indicates that large groves are the foundation of success ful conservation programs. Nonetheless, it was observed that both groves harbour a number of species that appear vulnerable to dynamics of forest frag mentation based on changes in their relative abundance across sites. The findings are discussed in the context of potential indicator species and theoretical predictions of at-risk species.
\end{abstract}

Keywords Butterfly Diversity, Sacred Grove, Fragmentation, Protected Areas

\section{Introduction}

Sacred groves sometimes referred to as sacred forests around the world represent a traditional form of community-based conservation. Throughout the ages, they have been protected for several generations for a variety of reasons including religious practices or ceremonies, as burial grounds and for their watershed value $[1,2]$. These community-protected forests are often associated with traditional regulations or rules such as taboos, totems and myths that deter human exp loitation with in the groves. These complex traditional rules have long preserved the integrity of sacred forests and appear to have a crucial conservation role in maintaining biodiversity in sacred groves. There are an estimated 2,000-3,200 sacred groves in Ghana, about $80 \%$ of which occur in the southern half of the country[3]. They ranged in size from hundreds of hectares of forest to small

* Corresponding author:

ngansobeatrice@y ahoo.com (Beatrice T. Nganso)

Published online at http://journal.sapub.org/zoology

Copyright (C) 2012 Scientific \& Academic Publishing. All Rights Reserved areas of about 0.5 ha containing single trees or a few stones[3]. Sacred groves in Ghana were once part of continuous forest cover, but now mostly exist as relict forest patches embedded in an agro-pastoral landscape[4]. In some regions in the country, sacred groves also represent the only remaining examples of old growth forest vegetation harbouring rare, endemic and/or endangered species [5]. It is in this context that these indigenous forests can be used to guide reforestation or ecosystems recovery efforts in a landscape increasingly devoid of forested areas outside the existing protected area network. Ghana's sacred groves have also been adopted as one of the in situ strategies to mitigate the loss of biodiversity[6].

Despite their high conservation value, Ghana's sacred groves have been completely destroyed and/or reduced in size[7]. This situation could be attributed to (i) rapid population growth and its attendant problems of urbanization, migration, and resettlement, (ii) increased dependence on western technology, and (iii) the growing influence of foreign religions and beliefs[8]. In an attempt to conserve these indigenous fetish forests,[9] outlined a management strategy for Ghana's sacred groves that advocates the 
following: (i)Legislation to reinforce the traditional regulations regarding use and access; (ii) Provision of resources to improve local people's capability to manage their groves; and (iii) Nationwide inventory of the groves and the biological resources they contain. Concerning the nationwide inventory of biological resources within sacred groves, most surveyshave focused on their botanical, ethno-botanical or socio-cultural functions[10, 11]. Few attempts have been made in the country to assess the diversity of insects in sacred groves. Comprehensive and long term studies are needed to assess the diversity of insects in all sacred groves in Ghana in order to better understand their crucial role in in situ conservation of biodiversity. The presentstudy was therefore undertaken to assess the extent to which some sacred forests may contribute to the conservation of the country's forest-butterfly species. To this end, a comparative analysis of butterfly commun ity structure of the Abiriw and Odumante sacred groves in the Eastern Region of Ghana was conducted to assess their relative similarities and dissimilarities. The focus of this study was on isolated forest fragments in the Moist Semi-Deciduous Forest Zone of Ghana, the region of the country where remaining forests are most imminently imperilled.

A focal group of insect, the butterfly species, was used to quantify two aspects of community diversity, species richness and species composition, in the two forest fragments. Butterflies have been beneficially exploited in studying numerous aspects of tropical forest ecology in natural, managed and degraded ecosystems. This is largely because member species show a diversity of relative sensitivities to environmental change, and they are tightly intertwined with ecological systems as both primary consumers (herbivores) and as food items. An assessment of the abundance and diversity of butterfly species in sacred groves can therefore indicate the role of sacred groves in biodiversity conservation, and also serve as a good indicatio $\mathrm{n}$ of the health of the environment in and around the groves.

\section{Materials and Method}

\subsection{Study Sites}

The forests of Ghana comprise four increasingly dry vegetation zones. These are arranged as concentric bands, beginning with the Wet Evergreen Forests in the southwestern corner of the country, extending outward through the Moist Evergreen, Moist Semi-Deciduous, and Dry Semi-Deciduous Forest Zones[12]. The study was conducted in two isolated forest fragments namely Abiriw $\left(05^{\circ}-48^{\prime} \mathrm{N} ; 00^{\circ}-06^{\prime} \mathrm{W}\right)$ and Odu mante $\left(08^{\circ}-82^{\prime} \mathrm{N} ; 00^{\circ}\right.$ $\left.02^{\prime} \mathrm{W}\right)$ groves both located in the Moist Semi-Deciduous Forest Zone of Ghana.. The Abiriw and Odumante groves are located in the Akwapim North and South Districts respectively of the Eastern Region of Ghana (Figure 1). The sacred groves range in size from $400 \mathrm{~m}^{2}$ to $250 \mathrm{~m}^{2}$. Individual sacred groves fall under the jurisdiction of local traditional councils, and permission from village elders to enter and collect from each grove was required and secured. The Abiriw sacred grove is a gazette reserve called the Bosompra Forest Protected Area; meanwhile the Odumante grove is a long protected sacred grove. Each sacred grove is completely surrounded by an anthropogenically derived farm bush savannah matrix. The Abiriw grove contains the Bosompra stream, wh ich is the main water body draining the Abiriw township. Due to laxity in enforcing some of the customary laws that deter human exploitation of the forest resources, there has been increasing over-exploitation of these resources (e.g. logging, fuel wood harvesting, farming etc.) in the Abiriw grove. The Odu mante grove has been well preserved for several generations however, due to the economic constraints that local communities are facing, the grove is exploited for fuel wood, used as a burial ground by local people and a site for acting of local movies.

\subsection{Sampling Methods}

Typical fruit-baited charaxes traps and transect walk-and-counts were used to sample butterflies. One transect of $250 \mathrm{~m}$ was established from the edge of the forest to the forest interior and 5 charaxes traps were hung in each sacred site. Individual traps within areas were separated from each other by at least $50 \mathrm{~m}$ and by no more than $250 \mathrm{~m}$. Conscious effort was made to set up all traps in similar micro habitats within areas of closed canopy forest. Sampling was carried out monthly during the rainy season (June, July and October) and dry season (December, January and February). Sampling was done during these months based on the availability of local field guides in the respective sacred sites. Sampling at a given site consisted of baiting the charaxes traps with mashed, fermenting or rotting banana with beer and retrieving trap collections after 4 days. At each site, one transect route and edges of the sacred grove were walked to sample butterflies. Sampling was done under sunny conditions mostly between 9:00 am and 4:00 pm. All butterflies seen within $2.5 \mathrm{~m}$ on either side of the transect route and edge of sacred grove and up to $5 \mathrm{~m}$ in front of the observer were recorded[13]. For those that could not be identified on the spot, photographs were taken with a digital camera for later identification.

\subsection{Species Handling and Identification}

Standard field handling of specimens captured from charaxes traps consisted of firmly squeezing the thorax to disable the specimen[14]. The specimens were placed in glassine envelopes and stored for subsequent laboratory processing comprising identification, drying, spreading, pinning, photographing and labelling. Each processed specimen was labelled with a unique code that describes the exact place and date of collection. Butterflies collected were identified to the species level using a variety of taxonomic treatises, including[15],[16], and[17]. Difficult specimens were identified in consultation with $\mathrm{Mr}$. A. R. Sig ismund, an expert on insects and butterfly identification in Ghana. 


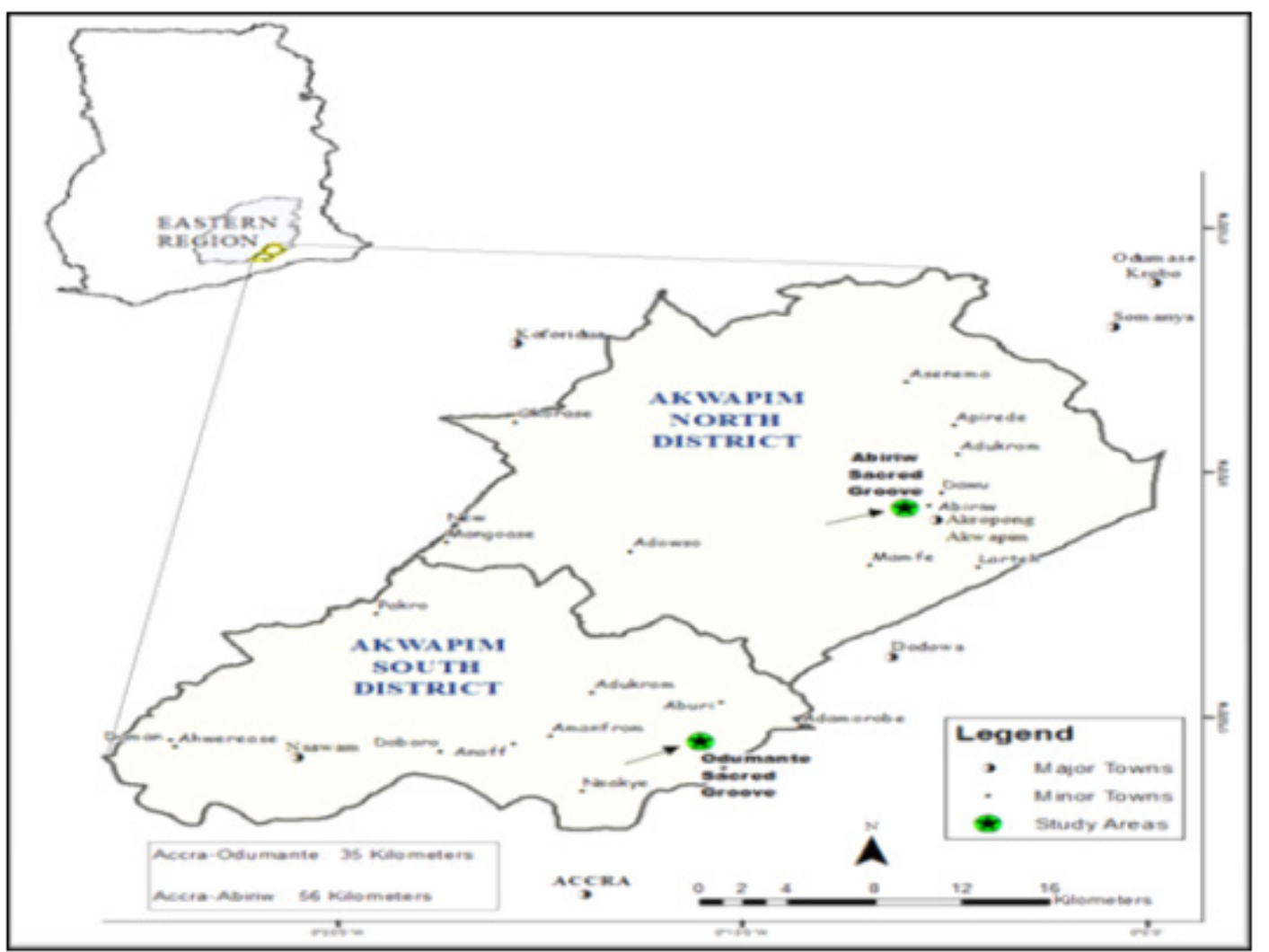

Figure 1. Map showing Abiriw and Odumante Sacred Groves in the Akwapim North and South Districts in the Eastern Region of Ghana

\subsection{Data Analysis}

Data from the two sources (fruit-baited charaxes traps and transect walk-and-counts) were pooled to obtain total butterfly diversity per study sites and per sampling period. The Student $t$-test was used to test the significant variation in the number of butterflies per family between sites, the total butterfly abundances between sites and between the wet and dry season in each grove[16]. For each site, the overall species accumulation curve was generated using the EstimateS program, Version 8.0[18]. The nu mber of samples was used as the index of sampling effort. EstimateS was also used to compute richness estimates based on a variety of nonparametric estimators such as: e.g. Chao1, Chao2, ICE (Incidence-based Coverage Estimator), ACE (Abundance-based Coverage Estimator), Jackknife 1 and Jackknife 2 for Abiriw and Odumante sacred groves. The Margalef, Shannon-Weiner and Simpson species richness and diversity indices were computed for each site and for the wet and dry season in each site. The similarity or complementarity between sites and the wet and dry seas on in each site based on the number of shared species among the butterfly fauna was measured using the Morisita-Horn index (MHSij) and the Bray-Curtis index (Sjk)[19]. The computation was carried out using the EstimateS program.

\section{Results and Discussion}

\subsection{Butterfly Abundance in the Respective Sacred Groves}

Each site was sampled 6 times throughout the course of the study, resulting in a total of 1169 individuals captured across all sites combined. Eighty nine species were collected in total from all sites combined, belonging to ten families (Appendix 1). All but nine of the 89 species collected (Papiliodemodocus, Catopsiliaflorella, Euremahecabe, Mylothrischloris, Danauschrysippus, Amaurisniavius, Melanitis Leda, Hypolimnasmisippus and Junoniaoenone) are comfortable in closed forest in good condition[20]. Five butterfly species (Bicyclussafitza, Melanitisleda, M. libya, Ypthimomorphaitonia, and Charaxes varanes), which are endemic to the forest habitat were collected in four sacred groves and two forest reserves during a year-long survey of fruit-feeding butterfly conducted by[4] in Kumasi, Ashanti Region of Ghana. Three of these species (Bicyclussafitza, Melanitisleda and Charaxes varanes) were trapped in the Abiriw and Odumante sacred groves. All but thirteen of the 89 species are specialized on savannah habitat (Appendix 1). Greater than $60 \%$ of those collected are considered either mo ist forest specialists or species found in all forest subtypes, which is as expected given the location of our study sites well within the Moist Semi-Deciduous Forest Zone.

In both sacred groves, the two families that recorded the highest butterfly abundance and richness were the Nymphalidae and Pieridae families (Table 1). Our study represents the first comprehensive butterfly survey in the Odumante grove. Although butterfly survey has been conducted in the Abiriw grove in the past, butterfly species and numbers recorded were lower than that for this study.[20] 
recorded 207 individuals belonging to 51 species from 8 families during a 2-day collection with no Lycaenidae and Riodinidae recorded. Only one charaxes species (Charaxesprotoclea) was recorded. The relatively low species richness recorded during Boafo's survey is consistent with theoretical expectation of short term insect's inventory, whereby rapid assessment tends to be biased toward common well known species[21]. The rapid survey might have missed important rare species, which in ecological studies are very important from the conservation viewpoint. It can therefore be deduced that, ourstudy represents the first comprehensive and long term butterfly survey in the Abiriw grove because more species were recorded with increasing sampling effort.

Table 1. Summary of butterfly individuals captured by family and habitat

\begin{tabular}{cccc}
\hline Family & Abiriw & Odumante & P-probability \\
\hline Papilionidae & 39 & 26 & $\mathrm{P}=0.05$ \\
Pieridae & 189 & 117 & $\mathrm{P}=0.05$ \\
Lycaenidae & 30 & 11 & $\mathrm{P}<0.05$ \\
Acraeidae & 24 & 11 & $\mathrm{P}=0.05$ \\
Libytheidae & 1 & 0 & - \\
Charaxidae & 5 & 2 & $\mathrm{P}=0.05$ \\
Danidae & 33 & 10 & $\mathrm{P}<0.05$ \\
Satyridae & 96 & 46 & $\mathrm{P}<0.05$ \\
Nymphalidae & 338 & 145 & $\mathrm{P}=0.05$ \\
Hesperidae & 29 & 17 & $\mathrm{P}=0.05$ \\
Total family & 5 & 5 & \\
Total individual & 784 & 385 & $\mathrm{P}=0.05$ \\
number (N) & & & \\
\hline
\end{tabular}

*Two-sample paired t-test indicates differences in the total number of individual butterflies per family. Between sites, the total number of individual butterflies did not differ significantly (2-sample paired t-test, $\mathrm{P}$ 0.05

When comparing butterfly abundance of the different families recorded between groves, we found significant differences in Danidae, Satyridae and Lycaenidae families (Table 1). The total butterfly abundances do not differ significantly between sites and between the wet and dry seasons in each site (P 0.05, Two-sample paired t-test). One possible explanation could be that both groves are located in the same geographical zone and sampling was done under the same environmental conditions, with temperature generally high during the dry season, reaching $32^{\circ} \mathrm{C}$ as compared to the wet season, where temperature was generally below $24^{\circ} \mathrm{C}$ (Conste, 2012 Personnal communication).

\subsection{Observed Species Richness}

The observed species richness was higher in the Abiriw grove than the Odumante grove, indicating that the butterfly community at Abiriw is generally more specious than that at Odumante (Figure 2; Table 2).This is consistent with theoretical expectation of species-area relationship, whereby small areas tend to support fewer species[22, 23]. Not surprisingly, the Margalef index of species richness was higher in the $400 \mathrm{~m}^{2}$ Abiriw grove than the $250 \mathrm{~m}^{2}$ Odumante grove (Table 2). The Abiriw community had a relatively higher abundance. In communities such as Odumante that are dominated by a few very abundant species, the vast majority of individuals in the community will be of these few predominant species, whereas in communities such as Abiriw where species are equitably represented, randomly encountered individuals are more likely to be derived from different species, which according to[24] is a defining characteristic of a diverse community. This is corroborated by the higher Simpson and Shannon indices of diversity at Abiriw than Odu mante. These findings add to the already substantial body of data that indicate the primary success of biodiversity conservation hinges on protection of large habitat areas. At both sites, the species accumulation curves were clearly approaching an asymptote, indicating that species saturation had been reached and sampling effort was adequate (Figure 2).

The Abiriw grove has retained much of its closed canopy as compare to the Odu mante grove most probably due to its distance from the Abiriw village proper as well as its rural setting which may have probably helped preserve the grove's integrity and resident biodiversity. Abiriw, unfortunately, also proved to be imperilled due to laxity in enforcing some of the customary laws that deterred human exploitation of the forest resources in the past. Before the beginning of the dry season collection, local communities cleared the route along which sampling at the grove was done, uprooting virtually every old growth and trees during the festival ceremony. This could be one of the possible explanations for the fewer number of individual butterflies collected during the dry season as compared to the wet season. Again, this event stands as a clear testimony to the enhanced vulnerability of small isolated forests to further degradation[25]. The landscape matrix surrounding the Odumante grove is uniquely characterized by intensive residential and farming activities adjacent to, and in some cases within the premises of the grove. The grove is also used as a burial ground by the local communities and as a site for acting local movies. All of these activities have undoubtedly led to the degradation or disruption of key ecological processes in the groves. This highly transformed landscape matrix has most likely served to hinder emigration from and immigration of butterflies to this isolated forest.

In both sacred groves, butterflies were more specious and diverse in the dry seas on than the wet season (Table 3). Not surprisingly, the Margalef, Shannon and Simpson indices were higher in the dry season than the wet season (Table 3). As noted by several researchers $[16,17,26]$, many butterfly species may increase if summer temperature increases. During the survey, the temperature was generally high during the dry season, reaching $32^{\circ} \mathrm{C}$ as compared to the wet season, where temperature was generally below $24^{\circ} \mathrm{C}$ (Conste, 2012 Personal communication). However, it should be noted that other factors such as resource availability for adults and larval host-plants, behavioural traits and 
interaction with other species may explain this increase in butterfly richness and diversity during the dry season[27]. This underscores the importance of measuring and documenting local conditions on determining species composition studies, even though these factors were not adequately measured in our study.

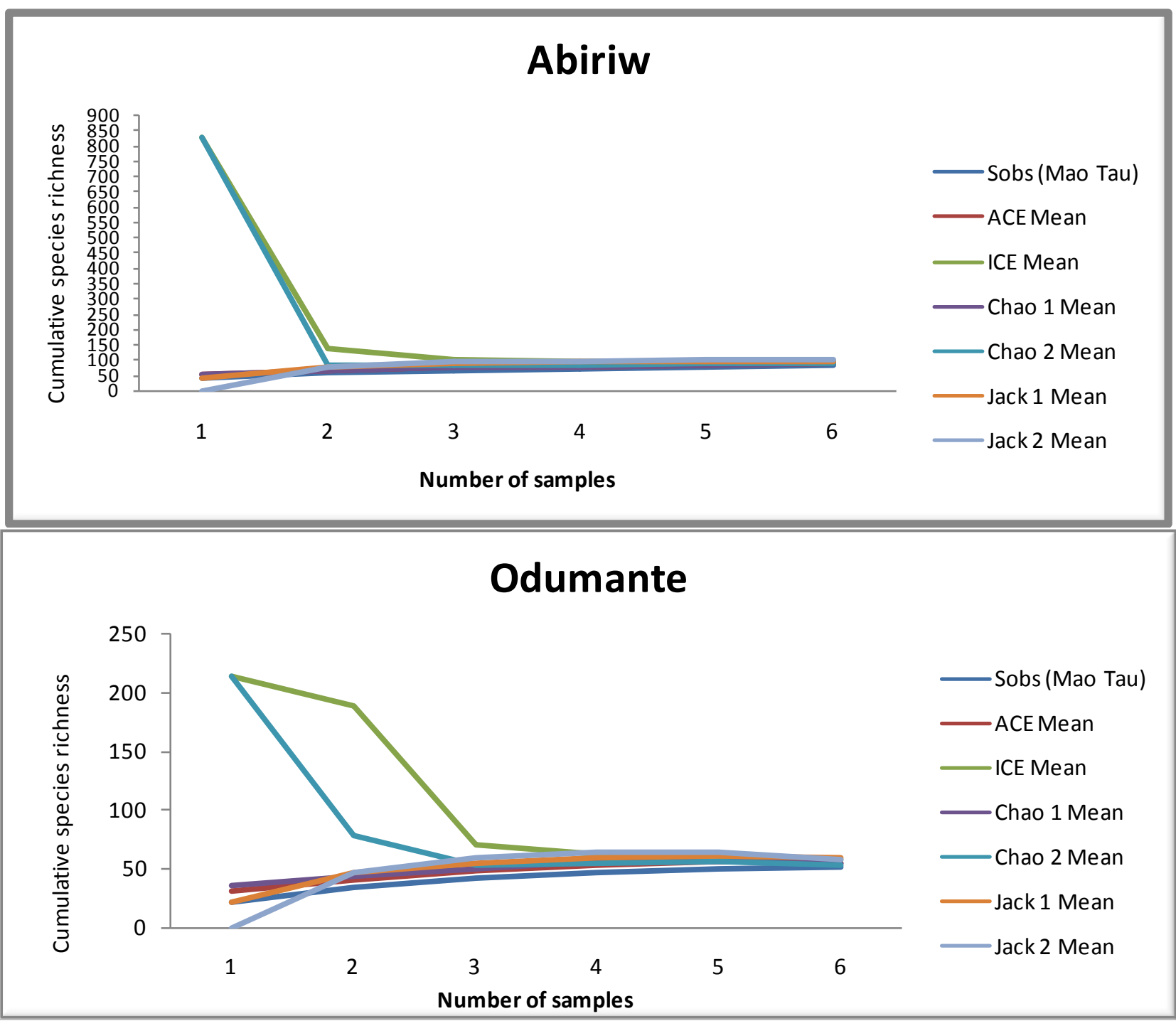

Figure 2. Randomized species accumulation curves. Number of observed and estimat ed species at each site as a function of increasing numbers of samples. Chao1, Chao2, ACE, ICE, Jack1 and Jack2 = non-parametric est imates of species richness; Sobs = act ual species observed in samples

Table 2. Species diversity dat a for each site

\begin{tabular}{|c|c|c|c|c|c|c|c|c|c|}
\hline \multirow{2}{*}{ Sites } & \multirow{2}{*}{$\begin{array}{c}\text { Total } \\
\text { species } \\
\text { trapped }\end{array}$} & \multirow{2}{*}{$\begin{array}{l}\text { Singletons/ } \\
\text { Doublet ons }\end{array}$} & \multirow{2}{*}{$\begin{array}{l}\text { Uniques/ } \\
\text { Duplicates }\end{array}$} & \multicolumn{3}{|c|}{ Est imates of total richness } & \multirow{2}{*}{$\begin{array}{c}\text { Additional } \\
\text { species } \\
\text { predicted }\end{array}$} & \multirow{2}{*}{$\begin{array}{c}\begin{array}{c}\text { Diversity } \\
\text { indices }\end{array} \\
\text { Simpson/ } \\
\text { Shannon }\end{array}$} & \multirow{2}{*}{$\begin{array}{c}\begin{array}{c}\text { Richness } \\
\text { index }\end{array} \\
\text { Margalef }\end{array}$} \\
\hline & & & & $\begin{array}{c}\mathrm{ACE} / \\
\mathrm{ICE}\end{array}$ & $\begin{array}{l}\text { Chaol/ } \\
\text { Chao2 }\end{array}$ & $\begin{array}{l}\text { Jack1/ } \\
\text { Jack2 }\end{array}$ & & & \\
\hline Abiriw & 83 & $13 / 10$ & $29 / 18$ & $76 / 226$ & $76 / 211$ & $84 / 80$ & $1-143$ & $45.01 / 4.03$ & 12.30 \\
\hline Odumante & 51 & $10 / 2$ & $19 / 12$ & $47 / 109$ & $49 / 85$ & $51 / 48$ & $34-58$ & $28.82 / 3.52$ & 8.40 \\
\hline
\end{tabular}

* Singletons and doubletons are the number of species repres ented by one or two individuals, respectively; uniques and duplicates are the number of species occurring in only one or two samples, respectively; Nonparametric richness estimators were used to estimate total species richness at a site; ACE and Chaol are abundance-b ased richness estimators. All others are incidence-b ased estimators; The number of additional species estimated to be at each site is the difference between estimated total richness and the number of species actually collected from traps; Simpson/Shannon diversity indices below the diagonal and Margalef richness index, where larger number indicates greater speci es evenness and richness 
Table 3. Diversity and richness indices for each season in each sacred grove

\begin{tabular}{cccc}
\hline Sites & \multicolumn{2}{c}{ Indices } \\
\cline { 2 - 4 } & Simpson (1/D) & Shannon-Weiner (H') & Margalef \\
\hline Abiriw wet & 32.10 & 3.73 & 10.52 \\
Abiriw Dry & 38.99 & 3.81 & 5.95 \\
Odumante Wet & 20.74 & 3.14 & 7.92 \\
Odumante Dry & 31.41 & 3.45 & \\
\hline
\end{tabular}

*Simpson (1/D), Shannon-Weiner and Margalef indices were calcul ated, where larg er numbers indicate greater species evenness and richness. Estimated species richness

\subsection{Esti mated $\mathrm{S}$ pecies Richness}

The observed number of species in any sample of individuals from a community underestimates the true number of species present. In statistical terms, observed species richness $\left(\mathrm{S}_{\mathrm{obs}}\right)$ is a biased estimator of the true richness for the assemblage sampled. Thus, a critical element of evaluating the performance of a species richness estimator is to assess how non-parametric richness estimators behave as a function of the number of samples [28]. These estimators helped in comparing the sampling effort and species realized to the estimated species richness.

At both sites, the observed species richness clearly underestimated the true species richness. The ICE (Incidence-based Coverage estimator) and Chao2 (Incidence-based estimator) were the only estimators that tended to level off with increasing sample size and produced stable and broadly accurate estimates at small numbers of samples (Table 2). In several studies that attempted to evaluate the performance of nonparametric estimators, ICE and Chao 2 have been reported to be the estimators that give promising estimate of the total species richness because they perform well at small sample size and are relatively insensitive to sample density and species patchiness [19, 29]. Other estimators tested fail to depict the true species richness. The Chaol and ACE estimators, for example, used abundance data and in this study underestimated the true species richness because they were many unique butterfly species than singleton butterfly species in the assemblage sampled (Table 2)[30]. The Jackkn ife 1 estimator performed better than the Jackknife2, especially at low sample sizes (Figure 2) when comparing the estimators in term of the ability to underestimate or overestimate (Bias) the true species richness. Earlier on,[31] reported similar result in their parasitological study in the United Kingdom. It therefore appears that Jackknife 1 is a less bias estimator than Jackknife2 even though little consensus on estimator variability has arisen from a broad collection of estimator performance studies. At Abiriw, the estimators predicted 1-143 additional species, while that for Odu mante; predicted 34-58 additional species (Table 2). Abiriw was thus predicted to have a more species rich butterfly community than Odumante.

\subsection{Site Complementarity}

A number of species were trapped at only one site (Appendix 1). Abiriw had, by far, the largest number of these at 38 , most of which were fa irly well represented. Six species were exclusive to the Odumante grove but nearly all of these were represented by two individuals.

The butterfly community at Abiriw and Odumante were closely similar (Table 4). Within the Abiriw grove, the Bray-Curt is index indicated greater commun ity similarity than the Morisita-Horn index when the wet and dry season communities were compared, meanwhile, within the Odumante grove; the Morisita-Horn index indicated greater community similarity than the Bray-Curtis index. In both sacred groves, the butterfly communities trapped during the wet and dry seasons were closely similar.

Table 4. Complementarity of species assemblages between sites and seasons

\begin{tabular}{cccc}
\hline Site & $\begin{array}{c}\text { Odumante } \\
(51)\end{array}$ & $\begin{array}{c}\text { Dry season } \\
\text { Abiriw (65) }\end{array}$ & $\begin{array}{c}\text { Dry season } \\
\text { Odumante (40) }\end{array}$ \\
\hline Abiriw (83) & $62 / 70$ & - & - \\
Wet season & - & $57 / 50$ & - \\
Abiriw (65) & - & - & $49 / 52$ \\
Wet season & - & - & 4 \\
Odumante (31) & - & & \\
\hline
\end{tabular}

*Bray-Curtis/Morisita-Horn quantitative indices of similarity (expressed as percentages ) below the diagonal. The total number of species trapped at each site is in parentheses for ease of comparison

This survey yielded a number of indicator butterfly species of forest condition, which can be beneficially exploited to help direct limited conservation resources in economically disadvantaged countries, e.g., to steer restoration efforts or identified priority sites for protection.

Six butterfly species (Papiliodemodocus, P. nireus, Bicyclusdorothea, Hypolimnasanthedon, Junoniaoenone and $J$. terea) were trapped at both sites despite differences in forest size and condition of individual grove. These species are known to be now much more common in West Africa than they ever were due to the widespread destruction and frag mentation of forest cover that has taken place in this part of Africa[17]. They are specialized in degraded habitats and open spaces and very few would ever be met within forest of good condition. The abundance of these species was higher 
in Odumante than Abiriw. This is somehow not surprising given the extent of habitat degradation that has taken place within the Odu mante grove. However, the presence of these species in Abiriw also tells us that some level of forest degradation has taken place within the grove; hence, these sixspecies can be considered as clear-cut indicator species of forest disturbance. In theory, these species are known to be generally common, to have fairly wide ranges and to colonise both intact and disturbed forests[17]. These are all characteristics, which according to[4] facilitate persistence of forest butterfly species in highly transformed landscapes. The grass-feeding butterflies belonging to the family Satyridae are also known to be good biodiversity indicators of forest condition. According to[32], their increased presence is an apparent sign of forest disturbance. More satyrine species were trapped at Abiriw than Odumante (Appendix 1), which is in agreement with earlier observation that the Abiriw grove has also undergone some level of frag mentation [33].

[17] found that certain butterfly species are vulnerable to habitat degradation. We found seven species, Papiliophorca s, P. menestheus, Cymothoemabillei, Catunaangustatum, Euriphene simplex, E. barombina and Charaxesprotoclea, to be those most sensitive to effects of forest fragmentation. Only three of the seven species were collected in Odumante, while only one of these species was not collected in Abiriw (Appendix 1). The abundance of these species in Abiriw grove was five times greater than that collected at Odu mante. Unlike rare species whose absence could relate to their lower overall probability and rate of capture, the decreased numbers of these common species are difficult to explain except in the context of sensitivity to dynamics of forest frag mentation.

\section{Conclusions}

Our preliminary assessment of butterfly diversity in habitat patches adds to the burgeoning evidence that sacred groves are potential storehouses of biodiversity in transformed landscape[34, 35]. These small forest patches are able to support resident populations of Charaxes $s p$., which are known as large and robust butterflies. In addition, a number of forest species endemic to the entire forest area West of the Dahomey Gap and West Africa (Papiliohorribilis, Hallelesishalyma, Euphaedra simplex and Pyrrhiadeslucagus respectively) were collected from the sacred groves. Thus, these relict forests are serving to foster persistence of forest species across a landscape matrix that is largely devoid of forest habitat. It is evident that sacred groves would not replace large forest reserves due to their relative s maller sizes. Rather, they could be a supplementary to forest reserves thereby enhancing more efficiently in situ biodiversity conservation in Ghana.

The traditional regulations or rules which previously prevented people from exploiting forest resources from the groves, however, appear to have been relaxed, resulting in general grove degradation. Despite the cultural and biological significance of Ghana's sacred sites, few receive active protection. Many have been completely destroyed and many others are under imminent threat by encroaching farms and residential development. Local communities are facing economic challenges posed by the modern world, and are therefore compiled to encroach the resources found within the groves. We, therefore, strongly recommend that an integrated approach to sacred grove management should be adopted in Ghana. Th is must take into account locals to serve as guardians within the framework of social forest conservation, private and cooperate organizations to help alleviate poverty in the local communities, scientific documentation of biological resources within the groves in different regions, campaigns and educational programmes highlighting the ecological and spiritual benefits of the forests for human sustenance, and a strong legislation to reinforce the traditional regulations regarding the use and access to sacred groves.

\section{ACKNOWLEDGEMENTS}

The authors are very grateful to the German Academic Exchange Service (DAAD) who funded the graduate research of TchuidjangNganso Beatrice at the African Regional Postgraduate Programme in Insect Science (ARPPIS), University of Ghana, Legon. We are also thankful to Mr. A. R. Sigis mund for willingly offering and providing his expertise on butterfly identification and on multiple of other issues concerning general butterfly information in Ghana. We are extremely indebted to the Chiefs and Elders of Akropong and Ketase, who granted access to the sacred groves. A number of different people provided invaluable help in trap installation at both study sites.

Appen dix 1. Butterfly species trapped at each site

\begin{tabular}{|c|c|c|c|}
\hline \multirow{2}{*}{ Species } & \multirow{2}{*}{$\begin{array}{c}\text { Forest Zone } \\
\text { Categories }\end{array}$} & \multicolumn{2}{|c|}{$\begin{array}{c}\text { Sacred Groves- } \\
\text { Abundance }\end{array}$} \\
\hline & & Abiriw & Odumante \\
\hline \multicolumn{4}{|l|}{ Satyridae } \\
\hline Hallelesishalyma & MF & 0.51 & 0.00 \\
\hline Mycalesissp. & $?$ & 1.66 & 5.71 \\
\hline Bicychusdorothea & ALF & 6.38 & 4.16 \\
\hline Bicyclussafitza & GUI & 1.53 & 0.52 \\
\hline Gnophodeschelys & ALF & 1.02 & 0.52 \\
\hline Gnophodesbetsimena & ALF & 0.77 & 0.00 \\
\hline Melanitisleda & UBQ & 0.38 & 0.26 \\
\hline \multicolumn{4}{|l|}{ Nymphalidae } \\
\hline Aterica galena & ALF & 1.40 & 0.78 \\
\hline Aterica $s p$. & $?$ & 1.40 & 0.00 \\
\hline Catunacrithea & ALF & 3.19 & 0.52 \\
\hline Catunaangustatum & MF & 3.95 & 2.60 \\
\hline Euphaedrajanetta & ALF & 1.40 & 0.26 \\
\hline
\end{tabular}




\begin{tabular}{|c|c|c|c|}
\hline Euphaedraxypete & MF & 1.15 & 0.78 \\
\hline Euphaedrasarcoptera & DRF & 2.68 & 5.45 \\
\hline Euphaedraharpalyce & ALF & 1.40 & 5.97 \\
\hline Euphaedramedon & ALF & 0.64 & 0.00 \\
\hline Cymothoemabillei & $\mathrm{MF}$ & 1.53 & 0.00 \\
\hline Cymothoeegesta & $\mathrm{MF}$ & 2.04 & 0.00 \\
\hline Cymothoefumana & $\mathrm{MF}$ & 1.40 & 0.00 \\
\hline Euriphene simplex & WF & 1.28 & 0.00 \\
\hline Euriphenebarombina & ALF & 1.40 & 0.26 \\
\hline Neptisnemetes & ALF & 0.25 & 0.00 \\
\hline Neptismelicerta & ALF & 1.02 & 2.60 \\
\hline Neptismetella & ALF & 1.02 & 1.04 \\
\hline Pseudacraeaboisduvali & DRF & 0.51 & 0.00 \\
\hline Pseudacraealucretia & ALF & 0.89 & 6.49 \\
\hline Phalantaphalanta & UBQ & 0.64 & 0.00 \\
\hline Hamanumidadaedalus & GUI & 0.25 & 0.00 \\
\hline Euphaedraedwardsii & ALF & 0.13 & 0.00 \\
\hline Ariadne albifasca & ALF & 0.38 & 0.00 \\
\hline Euryteladryope & DRF & 0.13 & 0.52 \\
\hline Junoniaoenone & UBQ & 6.12 & 4.68 \\
\hline Junoniaterea & ALF & 3.06 & 4.94 \\
\hline Junoniasophia & ALF & 1.28 & 0.00 \\
\hline Junoniachorimene & GUI & 0.38 & 0.00 \\
\hline Salam is cacta & ALF & 0.13 & 0.00 \\
\hline Hypolimnasanthedon & ALF & 0.64 & 0.78 \\
\hline Hypolimnassalmacis & ALF & 0.89 & 0.00 \\
\hline Hypolimnasmisippus & UBQ & 0.51 & 0.00 \\
\hline \multicolumn{4}{|l|}{ Liby theidae } \\
\hline Libytheanalabdaca & ALF & 0.13 & 0.00 \\
\hline \multicolumn{4}{|l|}{ Charaxidae } \\
\hline Charaxesvaranes & GUI & 0.51 & 0.26 \\
\hline Charaxesprotoclea & ALF & 0.00 & 0.26 \\
\hline Charaxesbrutus & DRF & 0.13 & 0.00 \\
\hline \multicolumn{4}{|l|}{ Danaidae } \\
\hline Danaus sp. & $?$ & 0.38 & 0.00 \\
\hline Danauschrysippus & UBQ & 1.91 & 0.26 \\
\hline Am aurishecate & ALF & 1.79 & 1.82 \\
\hline $\begin{array}{l}\text { Amaurisniavius } \\
\text { Pie ridae }\end{array}$ & UBQ & 0.13 & 0.52 \\
\hline Leptosiaalcesta & ALF & 2.55 & 0.64 \\
\hline Leptosia medusa & MF & 1.66 & 0.78 \\
\hline Leptosiamarginea & MF & 1.28 & 0.64 \\
\hline Belonois calypso & ALF & 1.77 & 2.08 \\
\hline Belonoiscreona & GUI & 0.13 & 0.00 \\
\hline Mylothrischloris & UBQ & 2.55 & 3.90 \\
\hline Mylothrisrhodope & MF & 0.13 & 0.00 \\
\hline Mylothrisjaopura & GUI & 0.00 & 0.52 \\
\hline Mylothrisschumanni & MF & 0.00 & 0.52 \\
\hline Nepheroniapharis & ALF & 1.28 & 6.75 \\
\hline Nepheroniathalassina & ALF & 2.17 & 2.34 \\
\hline Nepheroniaargia & ALF & 1.02 & 0.00 \\
\hline Colotisdanae & GUI & 0.51 & 2.60 \\
\hline Appiassylvia & ALF & 0.38 & 0.00 \\
\hline
\end{tabular}

\begin{tabular}{|c|c|c|c|}
\hline Appiassabina & MF & 0.25 & 0.00 \\
\hline Pierissp & $?$ & 0.00 & 0.52 \\
\hline Colotisevippe & UBQ & 0.13 & 0.00 \\
\hline Euremabrigitta & GUI & 2.55 & 2.34 \\
\hline Euremafloricola & GUI & 2.81 & 3.12 \\
\hline Euremasenegalensis & MF & 0.38 & 0.26 \\
\hline Euremahecabe & UBQ & 0.77 & 2.08 \\
\hline Colotisantevippe & GUI & 1.02 & 0.00 \\
\hline $\begin{array}{l}\text { Catopsillaflorella } \\
\text { Hespe riidae }\end{array}$ & UBQ & 0.77 & 0.00 \\
\hline Pyrrhiadeslucagus & DRF & 1.77 & 4.42 \\
\hline $\begin{array}{c}\text { Antheneliodes } \\
\text { lycaeni dae }\end{array}$ & ALF & 1.91 & 0.00 \\
\hline Oxylidesfaunus & MF & 0.25 & 0.00 \\
\hline Euchrysopsalbistriata & GUI & 0.89 & 1.56 \\
\hline Dapidodigma hymen & DRF & 2.66 & 0.78 \\
\hline $\begin{array}{l}\text { Euchrysopsreducta } \\
\text { Papilionidae }\end{array}$ & GUI & 0.00 & 0.52 \\
\hline Graphiumantheus & DRF & 0.25 & 0.00 \\
\hline Graphiumpolicenes & ALF & 0.51 & 0.00 \\
\hline Papiliodemodocus & UBQ & 2.30 & 3.64 \\
\hline Papiliophorcas & ALF & 0.25 & 0.00 \\
\hline Papiliobromius & ALF & 0.25 & 0.00 \\
\hline Papiliomenestheus & MF & 0.13 & 0.00 \\
\hline Papilionireus & ALF & 0.51 & 1.04 \\
\hline Papiliohorribilis & WF & 0.13 & 0.26 \\
\hline $\begin{array}{l}\text { Papiliodardanus } \\
\text { Acraeidae }\end{array}$ & ALF & 0.64 & 1.82 \\
\hline Acraeaalciope & ALF & 1.28 & 1.56 \\
\hline Acraeazetes & GUI & 1.66 & 0.52 \\
\hline Acraeamacaria & MF & 0.13 & 0.00 \\
\hline Acraeaepaea & ALF & 0.00 & 0.78 \\
\hline
\end{tabular}

*Numbers are relative abund ances based on the total sample size from that site. Forest zone categories are from Larsen (2005). Forest zone designations: WF, Wet forest; MF, Moist forest; DRF, Dry forest; ALF, All forest subtypes; GUI, Guinea Savannah; UBQ, Ubiquitous

\section{REFERENCES}

[1] Blench, R., Dendo, M. and Road, G., 2004, Cultural and biological interactions in the Savannah Woodlands of Northern Ghana: sacred forests and management of trees. Paper presented at the conference Trees, Rain and Politics in Africa, Oxford University.[Online]. Available: http://www. rogerblench.info/Ethnoscience\%20data/O xford\%20paper\%2 02004.pdf

[2] Malhotra, K. C., Gokhale, Y., Chatterjee, S., and Srivastava, S., 2007, Sacred groves in India. New Delhi, India: Aryan Books International.

[3] Gordon, C., 1992, Sacred Groves and Conservation in Ghana. Newsletter of the IUCN SSC AfricanReptile andAmphibian Specialist Group, 1: 3-4.

[4] Bossart, J. L., Opuni-Frimpong, E., Kuudaar, S., and Nkrumah, E., 2006,Richness, abundance, and complementarity of fruit-feeding butterfly species in relict sacred forest reserves of Ghana. Biodiversity and Conservation, 15: 333-359.

[5] Arhin, S., 2008, Complementing legislation: The role of cultural practices in the conservation of wildlife-examples from Ghana. Journal of Animal Law, 4:93-98.

[6] Attuquayefio, D. K., and Fobil, J. N., 2005,An overview of 
biodiversity conservation in Ghana: challenges and prospects. West African Journal of Applied Ecology,7: 1-18.

[7] Sarfo-Mensah, P., Oduro, W., Fredua, E. A., and Amisah, S., 2010,Traditional representations of the natural environment and biodiversity conservation: sacred groves in Ghana. FondazionEni Enrico Mattei, Working Papers, 24 pp.

[8] Decher, J., 1997,Conservation, small mammals, and the future ofsacred groves in West Africa. Biodiversity Conservation,6: 1007-1026.

[9] Ntiamoa-Baidu, Y., Gyamfi-Fenteng, L. J., and Abbiw, D., 1992,Management strategy for sacred groves in Ghana. Report prepared for the World Bank and the Environmental Protection Council.

[10] Amoako-Atta, B., 1995, Sacred groves in Ghana. In: Von Droste, B., Plachter, H. and Rossler, M. (eds). Cultural landscapes of universal value: Components of a global strategy. Gustav Fisher Verlag Jena, Stuttgart, 464 pp.

[11] Decher, J., Kilpatrick, C.W., and Bahian, K. L., 2001, Small mammal zoogeography and diversity in West African forest remnants. http://atidekate.com. National Geographic Society Committee for Research and Exploration and the Ghana Wildlife Division.

[12] Hawthorne, W. D. and Abu-Juam, M., 1995, Forest protection in Ghana with particular reference to vegetation and plant species. IUCN, Gland, Switzerland and Cambridge, Uk, 203 pp.

[13] Fermon, H., Schulze, C. H., Waltert, M. and Muhlenberg, M., 2001, The butterfly community of the Noyau Central, Lama Forest (Republic of Benin), with notes on its ecological composition and geographic distribution. African Entomology, 9: 177-185.

[14] Oduro, W. and Aduse-Poku, K., 2005, Preliminary assessment of fruit-feeding butterfly communities in the Owabi wildlife sanctuary. Ghana Journal Forestry,17 and 18: 9-19.

[15] Carter, D., 1992, Butterflies and moths.In: Edmonds, A., Dewhurst, H., Hewson, E., Bradley, J. D., Webber, C., Opler, A. and Wills, C. A. (eds). Stoddart Publishing Co. Limited, $304 \mathrm{pp}$.

[16] Belcastro, C. and Larsen, T. B., 2006,Butterflies as an indicator group for the conservation value of the Gola for ests in Sierra Leone. Report to the Gola Forest Conservation Concession Project.

[17] Larsen, T. B., 2005, Butterflies of West Africa. Apollo Books, 2:596.

[18] Colwell, R. K., 2000,EstimateS: Statistical Estimation of Species Richness and Shared Species from Samples. Version6.0b1. User's Guide and application published. [Online]. Available: http://viceroy.eeb.uconn. edu/estimates

[19] Magurran, A. E., 2004,Measuring biological diversity. Blackwell Publishing: Oxford, UK. 256 pp.

[20] Boafo, K., 2010,Butterfly diversity in the Abiriw sacred grove in the Eastern Region of Ghana. Unpublished B.ScDissertation.University of Ghana, Legon.

[21] Summerville, K. S. and Crist, T. O., 2002, Effects of timber harvest on forest Lepidoptera: community, guild, and species responses. Ecological Applications, 12: 820-835.

[22] Schoener, T. W., 1976,The species-area relationship within archipelagoes: models and evidence from island birds. Proceedings of the XVI International Ornithological Congress, 6: 629-642.

[23] May, R. M., and Stumpf, M. P. H., 2000,Species-area relations in tropical forests. Science, 290: 2084.

[24] Purvis, A. and Hector, A., 2000,Getting the measure of biodiversity. Nature,405: 212-219.

[25] Laurance, W. F., Ferreira, L. V., Rankin-de Merona, J. M. and Laurance, S. G., 1998, Rain forest fragmentation and the dynamics of Amazonian tree communities. Ecology, 79: 7032-7040.

[26] Pollard, E., 1988,Temperature, rainfall and butterfly numbers. Journal of Applied Ecology, 25: 819-828.

[27] Pinheiro, C. E. G. and Ortiz, J. V. C. (1992).Communities of fruit feeding butterflies along a vegetation gradient in Central Brazil. Journal of Biogeo graphy, 19: 505-511.

[28] Colwell, R. K. and Coddington, J. A., 1994, Estimating terrestrial biodiversity through extrapolation. Philosophical Transactions of the Royal Society London. Series B, 345:101-118.

[29] Chazdon, R. L., Colwell, R. K., Denslow, J. S., and Guariguata, M. R., 1996, Statistical methods for estimating species richness of woody regeneration in primary and secondary rain forests of NE Costa Rica. In: Dalmeier F. and Comiskey J.A. (eds), Forest Biodiversity Research, Monitoring and Modeling: Conceptual Background and Old World Case Studies. Parthenon Publishing, 289-313 pp.

[30] Chazdon, R. L., Colwell, R. K. Denslow, J. S. and Guariguata, M. R., 1998,Statistical methods for estimating species richness of woody regeneration in primary and secondary rain forests of north-eastern Costa Rica.In: Dallmeier, F. and Comiskey, J. A. (eds.). Forest biodiversity research, monitoring and modelling: conceptual background and old world case studies, Paris: Parthenon Publishing, 285-309 pp..

[31] Walther, B. A. and Morand, S., 1998, Comparative performance of species richness estimation methods. Parasitology, 116:395-405.

[32] Larsen, T. B., 1994, The Butterflies of Ghana - Their Implications for Conservation and Sustainable Use. Report to IUCN and Dept. of Game \& Wildlife, Ghana.

[33] Kangah-Kesse, L., Attuquayefio, D., Owusu, E. and Gbogbo, F., 2007, Bird Species Diversity and Abundance in the Abiriw Sacred Grove in the Eastern Region of Ghana, Department of Zoology, University of Ghana, Ghana Wildlife Society, Accra, Ghana.

[34] Bhagwat, S. A. and Rutte, C., 2006,Sacred groves: Potential for biodiversity management. Frontiers in Ecology andthe Environment, 4(10): 519-524.

[35] Tscharntke, T., Steffan-Dewenter, I., Kruess, A. and Carsten T., 2002, Contribution of small habitat fragments to conservation of insect communities of grassland-cropland landscapes. Ecological Application, 12: 354-363. 